\title{
THE QUESTION OF SURVIVAL: THE DEATH OF DESIRE AND THE WEIGHT OF LIFE
}

\author{
Leanh Nguyen
}

This article aims to document the psychic injuries of torture. Psychic deadness, erasure of intersubjectivity, refusal of meaning-making, perversion of agency, and an inability to bear desire constitute the core features of the post-traumatic landscape of torture. The existential challenges in traumatized lives is examined, and questions are also raised about the ethics and unconscious defensive functions of the term "survival." Clinical materials with various torture patients are reported to explore the process of working through the losses and paradoxes of trauma. The role of unmourned loss and the defense of fetishizing the trauma are highlighted as the motivating force and the problem in the current preoccupation with trauma in modern Western culture.

KEY WORDS: torture; survival; psychic deadness; desire.

DOI:10.1057/palgrave.ajp.3350007

\section{Vignette 1}

Marianne is a 22-year-old Senegalese refugee. When she was 19, Marianne was stopped on the road in the Casamance region. She was herded into a truck and sent to a detention camp, on the accusation of belonging to the opposition party. There, for 9 months, she was kept in a windowless cell, fed rotten food and minimal water, forced to urinate and defecate where she slept. Everyday she was taken to the field to perform meaningless back-breaking labor. There would be intermittent interrogations and beatings, accompanied by the occasional gang rape, to extract information about her alleged opposition activities.

After her release, Marianne fled to the US and was granted political asylum. She came to treatment with complaints of nightmares, flashbacks, startle response, acute shame, and a deep fear of people. She had no friends and no hope. Intensive therapy, combined with medications and social services, helped her recover a normal level of psychosocial functioning (e.g., school, employment, even reunification with her family).

Leanh Nguyen, Ph.D. is a senior psychologist at the Bellevue/NYU Program for Survivors of Torture. She is also a candidate at the NYU Postdoctoral Program for Psychotherapy and Psychoanalysis. She maintains a private practice in New York City.

Address correspondence to Leanh Nguyen, Ph.D., 345 7th Avenue, Suite 1602, New York, NY 10001; e-mail: leanhnguyen@hotmail.com 
But her internal life is barren, except for a thick, amorphous fear that she cannot articulate. She does not consider relationships relevant or accessible. The rhythms and hopes intrinsic to interpersonal interactions which we take for granted are incongruous to her. The future draws a blank in her mind. She thinks she would like to make a family some day, because she knows that this is what people do, and remembers that once upon a time she had dreamt of it. But it is an idea that floats like an inert picturelike a postcard of some attractive faraway land that prisoners pin on the wall of their cells. She does not engage in making any meaning of her life experiences. Being with her in our sessions, I often liken myself to doing CPR on a stillborn baby. She is a beautiful, physically healthy, intelligent young woman, but she feels nothing and is light-years beyond —or behindany 22-year-old we see walking in the streets of New York City.

\section{Vignette 2}

Throughout his twenties, because he was a student leader in the protest movement against the ruling government in a South Asian country, Raj was repeatedly detained and subjected to physical interrogations. He would also frequently witness people being beaten, shot, burned. His academic advancement was consistently thwarted. Not only were his prospects and safety compromised but his existence was a constant danger to those close to him, as his home was often raided and his parents terrorized.

Now in his late thirties, after having been in the US for 15 years, two doctorates, a failed marriage, Raj still lives out the dynamics of his trauma experience through a pattern of relating that is marked by narcissistic isolation and sadomasochistic enactments.

He came to treatment following a life-threatening hunger strike. A series of personal disappointments and a pervasive dissatisfaction with life had prompted him to apply for resettlement in another country. When his request was turned down by the UNHCR, he abandoned all life arrangements, checked himself into a homeless shelter, and went on a protest campaign, culminating in the hunger strike that landed him in intensive care and then the psychiatric unit.

Raj was convinced that he was deprived and persecuted by US policies and therefore refused to participate in any life activity in this country. He refused to engage in any meaningful relationship because he did not want to corrupt his self-sufficiency and did not want to be contaminated by disappointment or compromise. He summarized his state of being as "needing nothing, wanting nothing, not being attached to anyone or any country." And he justified his hunger strike as follows: "People have left me no choice. I cannot get rid of the fear that has paralyzed my life and 
cannot return to a normal life with purpose and dignity. I want to be as much of a burden to the system as possible so that they will have to give up and get rid of me."

His days would be spent camping out at the UN complex, denouncing the hypocrisy of US policies and the meaninglessness of life in modern society. He rejected all offers of assistance, all pleas to make use of his extraordinary education, all attempts from the system to negotiate some other way to register his discontent. He stood outside of normal living but was extremely willful and alive to his perverse purpose of re-enacting dynamics of aggression and coercion. Wherever he went (city hall, the UN, the INS, the emergency room) he would engineer situations where he would receive very special attention, would induce officials and care providers to feel puzzled, panicked, helpless, and eventually enraged, when they then would take actions that are tantamount to stripping him of the most basic self-determinism (via involuntary psychiatric hospitalization, forced intravenous feeding, threats to revoke his legal residency status, forced therapy).

In our sessions, Raj only allowed me to connect with him through debates of his ideological agenda and through torturous contracts for safety. He maintained a stance of interpersonal negation: There was no relationship between us; he had no expectation of me; there was no impact that we could make on one another. The personal he deemed "irrelevant." The experience of wanting he dismissed as "unproductive." Anything that confronted him with the reality of another person made him uncomfortable. Kindness or loving contact was equated with "complication" and the burden of being "tied up."

Here he was, years after his traumatic history, being on strike (literally and figuratively), refusing to participate in life, misusing his resources in the pursuit of some fantasied other land, exercising his agency toward situations where he would feel oppressed, misunderstood, and deprived. He had deadened his capacity to feel, except for an unshakeable sense of injustice. From having been repeatedly robbed of control, he now dedicated himself to constructing an artificial reality where he was insulated from mutuality and brooked no compromise. He had made himself impermeable to desire and disappointment. He literally did not see himself as human. In a deep sense, he had made himself not human (see Cooper, 1986).

By common standards, this man had survived his persecution and torture. But what do I see in his "survival" now? The belief in goodness and in the possibility of gratification has been replaced by the expectation of oppression. The desire and effort toward human connection has been deformed into the compulsive re-enactment of sadomasochistic transactions. The wish for love has been perverted into the pursuit of rejection. The hopeful 
illusion of control and communion, which we all rely on to make our ways through this world (see Sullivan, 1946), has been stripped into the single-minded demonstration of invulnerability and alienation. Survivor or victim, he is deadened to life and imprisoned in some inhumane psychic space.

\section{INTRODUCTION}

Trauma seems to be at the forefront of most clinical as well as sociopolitical debates in recent years. One can certainly point to the ravages of $9 / 11$ as the trigger for the mobilization. However, from my vantage point of a clinician who has been steeped in the world of war trauma and political persecution over many years, I believe that the fissures occasioned by the WTC attack, and the ensuing preoccupation with trauma at all levels of discourse from all disciplines, speak of some deeper need. It seems that we are galvanized by this topic in search of a way to articulate and resolve some underlying collective psychic injury.

The mention that I work with survivors of torture invariably evokes a great amount of interest. People inquire about what my patients "look like" but also about what it must take to work with them. In other words, patients who have been tortured and traumatized, as well the clinicians who dip into their psychic world alike, are elevated into a different status. The implicit assumption is that these people stand apart, that they belong to a different category, move in a different emotional, moral, existential, and clinical dimension. It is assumed that the patients must have experienced something that defies ready, worldly comprehension; likewise, it is assumed that the clinician who treats them must be witness to something extraordinary and must know something that could expand (or threaten) our imagination of what it means to be human. The reactions about trauma/torture contain a deep concern about matters of living, suffering, losing, and dying. In the curiosity about this particular region of the psyche seems to be some manifestation of our unspoken collective search for the definition of a meaningful, intact life. By way of inquiring into the defamation and perversion of these lives we, maybe, look to contain our grief and anxiety about the injuries, failures, and lacks that are perpetrated in our contemporary culture.

In brief, I am implying here that there is a measure of fetishization of trauma. And, if so, it would behoove us well to look further into the unarticulated anxiety and injury underneath such interest. I feel enormously privileged to participate in this special issue and hope that I add something worthwhile to the body of knowledge. But I do not want to lose sight of two important issues: 
First, what constitutes trauma? Like erotic desire, or joy, or terror, it seems that trauma is that thing of the human experience that both defies articulation and yet is recognizable to all. And so, as we search to capture the traumatized subject, are we not also searching to articulate what it means to be human?

Second, what does it mean to "survive" trauma?

I have noticed that in the clinical and political parlance regarding trauma/ torture/abuse, we have moved from "victims" to "survivors." This shift in semantics does not merely reflect the influence of post-modernist and humanistic sensibilities. It implies-dictates-a particular trajectory that may speak more of the agenda and flight of the observer-clinician-policy maker than the actual reality of the trauma patient. It implies, hopefully and erroneously, that a life interrupted by gratuitous sadism, inexplicable violation, and systematic annihilation can be restored and revived.

What kind of life is possible for patients whose sense of integrity and control has been annihilated? What does it mean to be human after one has been dehumanized? How does one live after having known death? What is the model of mind, the conception of humanity that could address the deadened psychic space that these patients live in? How do we make room and address the walking dead among us? When we seek to make contact with these patients, is it an attempt to heal or a disguised denial of our own death anxiety? Herein is my perpetual struggle with the work of trauma: How do we join in without being submerged in deadness? Is our engagement with the traumatized subject a sign of fetishization, in disguise of our own inability to master the violations of our modern culture?

Over the past 5 years, I have been working with "survivors" of political torture and war trauma. The lives of these patients have elucidated for me that the trauma of violation, oppression, and annihilation, can mark you in many insidious ways. After the acute symptoms of post-traumatic stress have remitted, what the clinician is left to stare at is a degraded, perverted form of humanity - the incapacity to mourn the inadequacies and miscarriages of life, the killing off of curiosity and mutuality, the perversion of one's sense of agency, the sterilization of the capacity to receive and negotiate the complexities of human interactions.

The most terrible, and intractable, legacy of torture is the killing of desire-that is, of curiosity, of the impulse for connection and meaningmaking, of the capacity for mutuality, of the tolerance for ambiguity and ambivalence. For these patients, to know another mind is unbearable. To connect with another is irrelevant. They are entrapped in what was born(e) during their trauma, as they perpetuate the erasure of meaning, re-enact the dynamics of annihilation through sadomasochistic, narcissistic, 
paranoid, or self-deadening modes of relating, and mobilize their agency toward warding off mutuality, goodness, hope, and connection. In brief, they live to prove death. And it is this perversion of agency and desire that constitutes the deepest post-traumatic injury, and the most invisible and pernicious of human-rights violations.

Rather than combing the literature, I choose to invoke the words and lives of my patients to elaborate on my theoretical insights. These individuals were forced to know, intensively and ruthlessly, what we the ordinary living only know fleetingly. They have taught me what it takes to be human, through showing me how one can become dead to life. By their examples of negation, they have shown me that to be human requires the capacity to bear, without surrendering to, the reality of loss; the desire to know and love another while inhabiting the knowledge that connection cannot be absolute; the ability to be concerned and curious about another while recognizing that we all face death alone at the end of the day; the ambition to make our marks while knowing that everything we hold dear can be wiped out in one stroke; the pursuit in meaning-making in spite of, because of, the ineluctable fact of our ultimate insignificance in an impermanent, arbitrary world (see also Becker, 1973).

I will now describe one patient, who presents the most dramatic distillation of the dynamics prefaced above. My modest agenda is to illustrate the undercurrents and vagaries of the state of "survival."

\section{CASE BACKGROUND}

The patient is a 58-year-old Vietnamese refugee who came to the US 25 years ago. When he entered therapy with me, Mr. Dinh had been in and out of psychiatric treatment for 15 years, carrying the diagnoses of chronic post-traumatic stress disorder and major depression. The hope behind the referral to me was that a clinician fluent in his language and culture would have a chance with this patient whom everyone thought was a chronic, intractable case.

After the communists took over in Vietnam in 1975, Mr. Dinh was sent to a labor camp to be "re-educated" from his former pro-American affiliation. For 4 years, he was detained and tortured. After his release, like all other re-educated men, he was a stranger to his own family and was only allowed to live at the margin of the new communist society.

After a few months he fled on a boat. The circumstances of his escape were described in a de-realized manner: "I was roaming the beach at night looking for some catch. I saw a party of people scurrying in the dark. On impulse I joined them and landed in this country." 
He now lives alone in a single-room occupancy in the Bronx. Unable to work because of severely impaired concentration, debilitating depression, and a general intolerance for interpersonal contact, he subsists on public assistance. Although he has relatives in the area he avoids contact with them. His only sustained relationships are with service providers.

His daily functioning is hampered by flashbacks, intrusive thoughts, nightmares, and obsessive guilt about his wife and children in Vietnam. His physical health is also deteriorating due to high-blood pressure, heart ailments, and diabetes. Because of the history of dislocation and isolation, his relationships with his family (in Vietnam and the US) are marred by misunderstandings and estrangement, thereby limiting the possibility of connection. All of this Mr. Dinh enumerated to me with relish at our initial contacts-as evidence of the hopelessness of his life situation and as warning of the futility of any intervention on my part.

I know very little of his earlier life. He has refused to give me any biographical elaboration or emotional details. It is as if he does not have a past. I cannot hypothesize any developmental trajectory for his life before our meeting. It is as if time, a dimension so intrinsically connected to causality and thus emotional coherence and mortality (Brooks, 1984; Chasseguet-Smirgel, 1984), has stopped for this man.

\section{SUMMARY OF 3 THERAPY YEARS}

During the first year, he looked like a hollow shell of a man, the evidence of his sleepless nights, internal preoccupations, and interpersonal isolation etched on his face like dementia. He typically started each session by saying, "I suffer terribly" and then assailed me with tales of psychic torment (couldn't sleep, had flashbacks of his family, dreamt of the past, ruminated about how to get out of his life). These experiences were told as intractable, disembodied things. If I asked for elaboration he would dismiss by saying, "There is no need for details." If I invited him to look into the connections of events, he would ridicule me, "It's pointless. There is nothing more to this."

He devoted the whole first year of his therapy to show me that there was nothing I could do, that his life was an airtight chamber of purposelessness, isolation, arid grief, and endless ruminations about what he had lost.

I felt bound and gagged by this graphic but repetitive litany of unsolvable emotional dead-ends. I alternated between submitting to the deluge of suffering narratives, feeling resigned, defeated, and fighting for any possibility of change by coming up with counter-points, suggestions, interpretations, only to be met with "I can't" or "There is no use." Eventually, he did 
try out some ideas (e.g., to visit relatives, to join some group activity) to then detail back to me the proof of their futility. And his proof was quite lucid:

I cannot be with anyone. My family does not know me anymore. Nobody can understand the hell that is inside. What else is there to talk about with people? It's laughable to talk about work, stress, money, family. I have none of these. I have no life. My mind is going wild with thoughts that go round and round. I go crazy with this lonely conversation. I can't keep it quiet inside, but I can't talk to anyone. So I just talk into the air. People think I am crazy. But I am just crazy with loneliness.

He would fight my efforts to get close to him, smash my attempts to seize at the slightest opening of hope or curiosity, and refute all possibility of change. As he sought to strip me of any illusion of therapeutic potency, I struggled to join him in the airless, sterile place of his mind without becoming dead intellectually and emotionally. I fought to be with him without being like him, to experience the echoes of his trauma without succumbing to its conclusion.

When he said the following to me, was it pity or gratitude which produced the first moment of quiet intimacy between us?

Look, how can I convince you that my life is meaningless? What should I live for? What is there to live for? All my plans and dreams have vanished like waste water running down the gutter. I am just a leaf bobbing along the river of existence. I was squashed like a bug, and I am now existing like a bug. I breathe, eat, sleep, move my limbs, watch the days come and go. I have learned in my life that there is no control, no meaning. What's the point of you trying? I cannot work, cannot talk to people, cannot enjoy anything, cannot change anything in my situation. I cannot change what my mind knows, what it remembers. And I cannot have much of anything now anyway. It's over. Don't you see that there is nothing left for me to do now but wait for this body to expire?

Stepping into the second year, our sessions followed the same ritual, with the patient's opening announcement that his mind was broken and getting worse and followed with tightly argued proof of how he could not recover, could not form relationships, could not improve his physical health-how he could not and did not want to be a "normal" person. The sessions would always end with his thesis that "There is nothing that can be done. Nothing that can be different. I am just waiting to die. If only you could help me stop thinking and feeling."

I should also note that this negativism was complemented by a similar rhetorical stance. Everything was met with a passionate "No." The only time when he did not negate me was when I reflected back on the futility and hopelessness of his life. 
His soliloquies now would often conjure up in my mind the image of Sisyphus. And slowly I grasped that I could not, should not attempt to divert the plight or contradict his existential burden. I realized then his patience in the previous first year: He had been waiting for me to really, genuinely grasp, experience, and accept his position of psychic deadness. I now agreed that his life was a bombed out land where nothing would grow, that he was fated to mark the same endless hellish days over and over again, that there was no exit, no illusion of any "good, normal" life for him.

I should say here that he had yet to tell me about his torture history (and I had not asked him to). Avoidance this may be. But I understood that he was focused on telling me only the ruined aftermath, making me see the shelled-out dead man (as opposed to the "trauma") as he was encrusting himself behind the inert, repetitive narrative of the post-traumatic symptomatology, and convincing me that there was nothing I could do except to survey the enormity of his self-torture and to learn to accept the immutability of his position (see Havens, 1989; Phillips, 1995).

Once I grasped this narrative end, and the intentionality and psychic world-making that inhered in it (see Bruner, 2002; Freeman, 1993; Leavy, 1980; Schafer, 1983), I was able to surrender. I no longer felt defeated or gagged. Instead, I felt engaged, amused, even curious (about what variations on the same theme he would produce, about where in the stream I could enter). He still produced soliloquy-like theses and would compulsively undo my points, but there was a subtle change in his negativistic stance. Whereas before he would negate my mind by saying flat out "No, it's not that" he would now say "I was thinking about what you said, and here is where you are wrong." Words and thoughts were now passing back and forth between us in a combative, lively rhythm. Negation was still the modus operandi but our minds were acknowledged and allowed to make contact (see Austin, 1962).

The reported phenomenology of his suffering also shifted. He started to talk about desire. He described that wanting, longing, desiring caused him to suffer; that he could endure and be callused to everything except for "this sense of drive, of desire."

Concurrently, for the first time in 2 years of therapy he showed curiosity. Until then he had taken me as the latest arrival of the mental-health conveyor belt. Occasionally, he would toss out presumptive statements about my background and beliefs, statements that incited in me the urge to announce myself to him more distinctly but that he left withering in our constricted interpersonal space. Given this, the very first question that he ever asked me was astounding: "Where did you live in Vietnam?"

It turned out that he had spent his happy adolescent years in my native hometown. Any other living Vietnamese (or living person, how could one 
not?) would inquire further, but this man stopped short here. I was suspended between the native Vietnamese girl born in Nha-Trang and the American-trained psychologist working in New York City. Nothing else of history or developmental time was attached to me. He had wanted to know about me but did not let himself know too much. He was starting to take in the reality of me but was resisting stepping into a truly dialogic, mutual, shared space. It was as if he looked at me but did not touch or feel me.

A subsequent incident spoke to me further of his dilemma. I ran into him outside my office, as I was lighting a cigarette. He was quite startled. Looking curious, excited, taken aback, he inquired into my smoking and afterwork habits. He was addressing me as a person, with a life and limbs and face! I went along, freely disclosing. Just as I was wondering where the conversation would be heading next, his body movements became stiff, his speech was less fluent, and he abruptly took leave.

What had made him flee?

Smoking for women in our Vietnamese culture carries multiple connotations of sexuality, lifestyle, upbringing, class. It signals a life lived outside of conventions, a suggestion of something more, different, other.

And thus for a shattering wonderful moment he had collided into me as a living, breathing, sexualized being. The glimmer of excitement and curiosity that I saw told me that my patient was still psychically alive, albeit fighting to deaden it.

He ran away because he could not bear knowing more about me, lest the new shafts of knowledge would revive old desires. He aborted this little moment of life because he needed to pre-empt the separation that was creeping around the corner. Terminating the contact eliminated the precious ambiguity that was emerging. He was not dead, but was fighting to not be alive, because he could not bear the weight of knowing and did not know how to negotiate the ambiguity and discrepancy inherent in languaging and desiring (Carson, 1986; Kristeva, 1980).

Following this incident, Mr. Dinh disclosed that he had kept my name and phone number for 6 months before making the initial call for treatment. He was frightened of what longing the sounds of our language and the physical reality of a Vietnamese person could arouse in him.

He then spoke about his dilemma: He still desired but could not have. He craved human contact but could not bear the countless discrepancies in needs and meaning that come in human transactions. He could let himself wish for a female companion but did not know how to survive the guilt about his wife and how to manage the reality of another person. He had relatives in the area but avoided contact with them because he could not bear the proximity with their "happy normal life." He had former army 
buddies scattered throughout the US but felt futile about re-connecting because "we are just silent ghosts." And so he limits himself to interactions with healthcare providers, where the roles are prescribed, the interpersonal grounds are circumscribed, and desire and ambiguity in meaning are minimized.

What is the point of speaking, connecting, desiring? It is nullified by the sense of psychic exile. He explained to me:

I know things that you can't ever comprehend. I have seen too much. You have no idea how much. I can't ever tell anybody. There is no way that anybody, not even you with your learning and expertise, can ever fully understand.

Our aliveness is confirmed and honored by stepping into desire. Most of us, the fortunate ordinary ones, inhabit desire in spite of, because of, the margin between need and reality, between the original loss and the putative future recovery. Most of us go on speaking in spite of the possibility of not being fully understood. We try to connect while knowing that full, perfect connection is not possible. We make it our lifelong pursuit to merge the gap between private reality and public meaning. We are propelled by the possibility of bridging over to the vast terrifying promising universe that is the other person (see Eigen, 1992).

But this man who could be my father had been stripped of the hope/ delusion about this possibility. He knew "too much" of the impossibility and futility of such pursuit (see Wheelis, 1966). And he had needed me to also disillusion myself. I could now feel and be inside the nothingness of his experience, which informed what I voiced to him:

You have been tossed into a whole different universe of your own. Everybody else is over here, on one shore of life, and you are on the other side. I hear you tell me that you see no possibility of anyone bridging over to join you. And you have lost everything. I believe your dilemma now. What can you have that is tolerable, in light of the devastations of your life? What is the point of trying to have anything, when you live everyday in the knowledge of what is not possible? No repair can make up for what has been lost. I am foolish to want to connect you with life when you know so well the ways in which your life and mind are dead.

For the first time in this therapy, he did not contradict or prevaricate. Instead, he told me about his nightmares and flashbacks. He reminisced about his pre-war years as well as the trauma of his migration. I finally heard about his years of torture. He helped me visualize the acts of forced labor, starvation, forced feeding of rotten food, mock executions. I could imagine the rhythms of solitary confinements, staged confessions, savage beatings, as well as the slow-burning hardship of de-hydrating under the tropical sun, sleeping next to dying flesh, seeing his cellmates vanish, and wondering if his family knew of his existence. 
In his stories, what I know of his torturers is their facelessness and impenetrability. What seemed imprinted onto him during these 4 years were an intimate acquaintanceship with arbitrariness, unpredictability, lack of control, and meaninglessness. He was never able to fathom his torturers' motives. He remembered his trajectory of bewilderment, then clenched endurance, and finally the numbing and blanking of mind and body. "You stop questioning and just try to exist like an animal." Thus, mind-reading, then meaning-making, were gradually, inexorably suspended as the price of "survival."

Now, in the third year of our therapy, the patient announces often that he wishes to turn himself into "stone and glass," to reach a "non-human" state of "no expectation, no attachment, no desire, no memory." He complains of feeling pain from longing, loneliness, and purposelessness. Previously, he had insisted that "I want nothing out of life. I am just waiting to die." Now he wonders "How am I going to get through the rest of my life?" Before, he would throw his life situation at me like a traumatizing dead-end, he now brings it to me as a phenomenon, an unfinished map that we can look at together. In the place of the implacable negation, I now listen to the pained wonderment of "How will I bear the time that is left? Can there be anything for me?" Instead of reminding me of the lack of meaning in everything, he now talks about the suffering of finding no meaning. No longer deriding the possibility of connection, he now describes the sad irony of straddling two worlds (alive but deadened, deteriorating body but racing, longing mind, the Vietnam of his birth and trauma and the US of his "freedom" and emotional hell).

$\mathrm{He}$ has relented from the combative, negation-driven rapport to settle into a meditative, joint-musing rhythm. Instead of feeling talked at, blasted, or dumbfounded, I now feel addressed and in anticipation of his thoughts. I have the peculiar experience of thinking with him. We are not exactly together, not alike, but side by side. Neither companions nor adversaries, we are visitors-samplers of each other's existential landscape.

I paraphrase him, in our recent sessions, to render his landscape now:

I am sort of at peace. No more scurrying around in my mind like a rat looking for an exit. When I look back at my life, I see that we have no control. We are born and we die. In between it's all a joke, an illusion. Nothing makes sense. We run after money, sex, security. Desire can never be satisfied. And we all can lose everything in a split second, for no reason. I wonder why I have not gone insane from where I have been, from where I am now in my life. I don't know what to do with my mind though. Nothing I can do. So I keep my body alive. I put in food, go to sleep, take medicine. I know that we are all insignificant on this earth, millionaires and homeless alike. I am not afraid to die. But I ask you: What is the 
point? How can I get through this life? How many more years of this? Is this how I am going to get through the rest of my life?

\section{SUMMARY}

Now as we enter our fourth year together, Mr. Dinh addresses to me an explicit plea: "Can you help me figure out how to get rid of thinking and feeling?"

My accomplishment is bittersweet. I have succeeded in making him acknowledge his humanness. He knows that he is not made of "stone and glass." As Sullivan has said, we are all human, after all, but some are more than other. I also think of Albert Camus's reworking of the myth of Sisyphus to state a similar thing: We are all Sisyphus, each day fated to roll the boulder of life-thoughts, memories, wishes, fears-up some hopeful slope to only face the reality of loss, death, and pain. But some of us now are more conscious of that trajectory than others. And some of us manage that consciousness more creatively or authentically than others.

For this patient (like the countless others that have been tortured) knowing of the Sisyphean fate is his wisdom, but also his curse. Between illusion and disillusion, between hoping and losing, between the beginning ascent each day toward others and the inevitable end-of-the-day aloneness, there lies the heroic challenge of being human (Becker, 1973; Eigen, 1992). What distinguishes the true survivor from the walking dead is the capacity to bear the anxiety and emptiness of that paradoxical space-that is, the ability to find creativity from within the knowledge of death, to hold onto desire in the face of loss, to stay in relatedness and aliveness in spite of annihilation, to keep rolling while in acceptance of uncontrollability, futility, inevitability. At that crucial moment at the end of the day, at the end of the slope, at the point of the consciousness of being human (and all the pains and anxieties and promises that we carry in this life), some patients go dead, resigning themselves to the descent as if a death-in-life sentence, while others search for ways to imbue each repeated step with meaning and aliveness while in full recognition of the impermanence and violence of human existence (see also Russell, 1998).

\section{CONCLUSION}

Severely traumatized subjects, like my torture patients or Holocaust survivors, cannot balance this position because they know too much of one side of the paradox (Kertesz, 2004; Levi, 1986). The practice of torture is a rape on the hopeful, the controllable, the related, the 
meaningful. It violates the rationale for meaning-making, negotiating, planning. The stories of torture that I have heard all boil down to one narrative: The patient is thrown in a physical and moral universe where time, space, motivation, boundary, bodily functions, emotional rhythms, all are controlled and degraded by another human being who dictates the terms of the contact but whose motives you cannot comprehend. What seeps out of this intercourse and into their psyche is the helplessness of not being able to think about the other person's mind, the terror of not being able to predict the most basic interpersonal happenings, the intimate unambiguous, meaningless acquaintance with death.

What they know too much, too well, too irretrievably, is that there exists a dimension in this life where there is no meaning, no intentionality, no mutuality, where embracing death is the way to keep living, where shutting down one's mind and turning blind to the other's mind is the best way to survive. It is this knowledge, not the amputated limb or the torn vagina, which is the deadly blow.

At the end of the day, I am confronted with the knowledge that some lives cannot be repaired. Through moments of connection, I hold out for my patients the hope of something wondrous, but I am also the portent of renewed pain. "I can't bear to be alive," said one patient. And though I grieve for what has happened to him I know in that moment that we are different, and how I am more human than he. For I, and you who have seen the traumatized but have not been touched by trauma, can bear being alive, being in love, giving birth, preparing for death, even though we have been shown the dead (Eigen, 1992).

And so maybe we look into traumatized lives in order to figure out how to work out the way to remain intact in this traumatized, and traumatizing, culture. We look into that which has been de-formed and de-humanized in order to find our way to remaining human. We listen to these patients who embody what we may resist knowing about ourselves: That we in this modern technological culture are being gradually de-humanized, and are de-humanizing others; that we are being impoverished in our meaning-making capacity and our narratives of life; that we are ignorant, even negligent, in our dealings with psychic pain, with death and dying; that we are more and more alienated from the relevance and the ambiguity-laden task of human connection. We look into the plight of these patients in the hope of divining some means of repair (other than through medical and mechanical technology or warfare and litigious claims). And whether we recognize, fetishize, or exile this Sisyphus among us may determine the course of our collective recovery. 


\section{REFERENCES}

Austin, J.L. (1962). How to do things with words. Cambridge, MA: Harvard University Press.

Becker, E. (1973). The denial of death. New York: The Free Press.

Brooks, P. (1984). Reading for the plot: Design and intention in narrative. Cambridge, MA: Harvard University Press.

Bruner, J. (2002). Making stories: Law, literature, life. Cambridge, MA: Harvard University Press.

Carson, A. (1986). Eros the bittersweet. Princeton, NJ: Princeton University Press.

Chasseguet-Smirgel, J. (1984). Creativity and perversion. New York: Norton Books.

Cooper, A. (1986). Narcissism. In A. Morrison (Ed.), Essential papers on narcissism. New York: New York University Press.

Eigen, M. (1992). Coming through the whirlwind. Illinois: Chiron Publications.

Freeman, M. (1993). Rewriting the self: History, memory, narrative. London: Routledge.

Havens, L. (1989). A safe place. Cambridge, MA: Harvard University Press.

Kertesz, I. (2004). Fatelessness. New York: Vintage International.

Kristeva, J. (1980). Desire in language: A semiotic approach to literature and art. New York: Columbia University Press.

Leavy, S. (1980). The psychoanalytic dialogue. New Haven, CT: Yale University Press.

Levi, P. (1986). Survival in Auschwitz and the reawakening. New York: Summit Books.

Phillips, A. (1995). Terrors and experts. Cambridge, MA: Harvard University Press.

Russell, P. (1998). The role of paradox in the repetition compulsion. In J.G. Teichholz \& D. Kriegman (Eds.), Trauma, repetition, and affect regulation: The work of Paul Russell. Cambridge, MA: The Other Press.

Schafer, R. (1983). The analytic attitude. London: Basic Books.

Sullivan, H.S. (1946). Conceptions of modern psychiatry. New York: Norton and Co.

Wheelis, A. (1966). The illusionless man: Some fantasies and meditations on disillusionment. New York: Norton and Co. 